\title{
Małgorzata Mędrala
}

Katedra Prawa Publicznego

Uniwersytet Ekonomiczny w Krakowie ${ }^{1}$

Chair of Public Law

Economic University in Cracow

\section{WORKING ABOVE CONTRACTUAL HOURS IN THE CASE OF PART-TIME EMPLOYEES}

\begin{abstract}
The aim of the present study is drawing attention to a problem of employees who are employed on a part-time basis but work extra hours above the hours set out in their employment contracts but still below the statutory working time norm (further herein "contractual extra time" or "contractual extra hours"). The author analyzes three problematic issues in the present legal state: the part-time employees' duty to work extra hours, setting a contractual maximum of additional pay for part-time employees working extra hours, and sanctions relating to the failure of the parties to an employment agreement to specify the extra hours paid like for statutory overtime.
\end{abstract}

Słowa kluczowe: pracownik niepełnoetatowy, godziny nadliczbowe, godziny nadliczbowe ponad określony w umowie wymiar czasu pracy

Key words: part-time employee, overtime hours, contractual extra hours

\section{General remarks}

The current works of the Labour Law Codification Committee constitute an excellent opportunity to review some of the legal solutions in the Polish labour code that stir doubt from their axiological and practical standpoints. Such regulations include Polish provisions of law concerning employees who are employed on a part-time basis but work extra hours above the hours set out in their employment contracts but still below the statutory working time norm (further herein "contractual extra time" or "contractual extra hours"). In this context, against the background of judicial decisions, I notice

${ }^{1}$ Publikacja została dofinansowana ze środków Uniwersytetu Ekonomicznego w Krakowie na badania dla młodych naukowców i uczestników studiów doktoranckich (The publication was financed by funds of the Economic University in Cracow for scientific researches to the young scholars and participants of PhD studies). 
three problematic issues in the present legal state: the part-time employees' duty to work extra hours, setting a contractual maximum of additional pay for part-time employees working extra hours, and sanctions relating to the failure of the parties to an employment agreement to specify the extra hours paid like for statutory overtime.

It is worth starting our considerations with a discussion of the underlying purpose and nature of part-time employment. Part-time employment is atypical employment. It is full-time employment that should constitute the rule. Frequently, the decision on part-time employment arises out of the parties' willingness behind which stand various social, family, and other considerations attributable to the employee, like their providing childcare, studying, or additional activities after work. At times, the reason for such a choice is just lack of the need to work in a longer working time. In such a case, the employee does have a right to use their remaining free time in another way, especially for some extra work. However, typical employment should be full-time employment. The view is supported by the employer's duty to inform the employees, in a standard method used at the employer's, about the possibility of full-time or part-time employment and, in relation to employees employed for a definite period of time, about vacant job positions, as per art. $94^{2}$ of the labour code.

Also, the latest literature points out to the situation where the employer may offer to an employee part-time employment only when he has no possibility to employ them full time. Employers must not offer part-time employment if full-time employment is available or offer employment in less working time when the demand for work is higher, albeit not full-time. ${ }^{2}$

It should be noted that working time norm (art. $29 \$ 1.4$ labour code) is a significant element that should be set out in one's contract of employment. Should the parties agree on part-time employment, they should specify the length of one's working time. An analogous situation applies to one's choosing a limited term employment contract. The selection must follow directly or by implication from the parties' willingness. If the parties fail to disclose their willingness, then employment for an indefinite period is accepted as grounds for the establishment of an employment relationship. ${ }^{3}$

\section{The issue of overtime in the case of part-time employees}

Judicial practice points out that part-time employees are subject to the same working time norms as full-time employees. ${ }^{4}$ Overtime provided for in the Act on labour law (further herein "statutory overtime") starts only upon crossing the threshold of the

2 See A. Sobczyk, Prawo do pracy a zatrudnienie terminowe i niepetnowymiarowe, Praca i Zabezpieczenie Społeczne 2016, 11, p. $4 \mathrm{ff}$.

${ }^{3}$ M. Tomaszewska, Commentary to art. 29 of the labour code, thesis 11, in: Kodeks pracy. Komentarz, K.W. Baran (ed.), Warszawa 2016.

${ }^{4}$ See inter alia Supreme Court Judgment of 09 August 1985, I PRN 64/85, OSNCP 1986, No. 5, item 79. 
statutory working time norm, e.g. in the case of standard working hours (i.e. full-time employment) - upon exceeding eight hours per day or forty hours on average per week. For part-time employees, the extra hours within these limits are not statutory overtime even if the employee is entitled to remuneration for some of such hours like for statutory overtime. ${ }^{5}$ The statutory working time norm is, as mentioned below, identical for employees employed full-time and for the employees employed part-time. ${ }^{6}$ No grounds exist to accept that art. $151 \$ 5$ of the labour code, which lays down the rules of settling the remuneration for working extra time arising out of a part-time employee' employment contract, qualifies the work defined in the article as work in statutory overtime. The provision establishes only the terms of payment and the amount of extra pay for the working time exceeding the one set out in the contract. ${ }^{7}$

Although in the literature voices can be heard that describe such working hours as a new category of overtime hours, ${ }^{8}$ I am of the opinion that, in the light of provisions of art. $151 \S \$ 1$ and 5 of the labour code and of general provisions of the code concerning working time, such a position is difficult to accept.

At present, the key regulation concerning working extra hours for part-time employees is art. $151 \$ 5$ of the labour code under which the parties to an employment contract set out in their contract the admissible number of hours above the working time specified in the employment contract, which, if exceeded, entitle the employee to a remuneration bonus referred to in art. $151^{1} \S 1$ of the labour code in addition to their regular remuneration. The obligatory character of this provision is prejudged by the wording: "the parties set out." Without this regulation, part-time employees could, as a rule, have the right to remuneration for working overtime only after exceeding the norm of eight hours of work per day and forty hours per week.

Due to the varied daily working time of part-time employees and their providing work on different days of the week ${ }^{9}$ the question arises to which working time, i.e. the daily or weekly working time, the relevant contractual provisions should refer to as the regulation refers only to daily compensation as per art. $151^{1} \$ 1$ of the labour code. The functional reasons speak, however, in favour of the position that this term should include both one's exceeding the daily norm and the weekly average. Państwowa Inspekcja Pracy (National Labour Inspectorate) accepts four ways in which the number of working hours can be determined, upon exceeding of which the employee is entitled to a remuneration bonus like for statutory overtime. The limit of overtime can be indicated in relation to:

${ }^{5}$ See A. Kolosa, Zdaniem Państwowej Inspekcji Pracy, Praca i Zabezpieczenie Społeczne 2005, 11, p. 32.

${ }^{6}$ B. Lenart, Praca w godzinach nadliczbowych. Thesis No. 1, Służba Pracownicza 2004, 6, item 7.

7 A. Ornowska, A glos to the Supreme Court Judgment of 09 July 2008, I PK 315/07. Thesis No. 1, Przegląd Sądowy 2010, 11-12, item 194.

${ }^{8}$ See M. Kowalczyk, Dopuszczalna liczba godzin pracy ponad określony w umowie wymiar czasu pracy, Monitor Prawa Pracy 2010, 4, p. 217.

9 An employee can work only on some days of the week for a different or the same number of hours, e.g. in the case of a part-time employee: 2 days in a week for 8 hours and once a week for 4 hours, or every day for 4 hours. 
the working time in a job position (e.g. working over $3 / 4$-time $)^{10}$, the number of working hours in a reference period, the number of working hours in a week, and the number of working hours within 24-hour employee work cycle. ${ }^{11}$ The legal doctrine points out that the parties should not determine only the daily limit but include in the contract the weekly limit as well. ${ }^{12}$ Apart from the ways of stipulating the limit, the National Labour Inspectorate also accepts that the number of hours within a reference period be specified upon exceeding of which the employee shall have a right to a bonus. ${ }^{13}$

\section{Refusal to provide work in extra time}

Considering the aim and the background of part-time employment, the question arises whether a part-time employee is obligated to work above contractual working time according to the same rules as a full-time employee who is working in statutory overtime and what remuneration should such a part-time employee receive in such a situation.

Judicial decisions indicate ${ }^{14}$ that, due to the duty to have regard for the welfare of the employer, an employee as a rule should not refuse to work in additional time. Moreover, the request to work additional hours does not require the existence of prerequisites that are typical for statutory overtime ${ }^{15}$ nor are they counted toward the annual limit of overtime hours. ${ }^{16}$

On the other hand, however, it should be noted that, when employed part-time, the part-timer's employment contract in general does not give them a full source of income for him and his family. Thus, the employee earns some extra money somewhere else or other reasons for one's conclusion of a part-time employment contract exist. Therefore, a possible collision with the employee's other activities should be taken into account.

${ }_{10}$ The doctrine also indicates such a possibility; see P. Wąż, Problem pracy ponad niepetny wymiar wynikajacy z umowy o prace, Monitor Prawa Pracy 2009, 11, p. 566.

11 Limit normalnej pracy na część etatu wskazujemy na cztery sposoby, Rzeczpospolita, 01 June 2007, df 2 and the position of the National Labour Inspectorate quoted therein.

12 K. Stefański, \$ 3.2. Godziny nadliczbowe pracowników niepełnoetatowych, in: Czas pracy, Z. Góral, K. Stefański (eds.), LEX 2013.

13 See Ł. Pisarczyk, Commentary to art. 151 of the labour code, in: Kodeks pracy. Komentarz., L. Florek (ed.), LEX/el. 2011.

14 See e.g. justification of the Supreme Court Judgment dated 04 April 2014, I PK 249/13, LEX, No. 1441344.

15 In accordance with art. $151 \S 1$ of the labour code, the work provided by an employee above the norms of working time and the work performer in excess of the extended daily work limit that the employee is obligated to perform pursuant to the work system and schedule constitutes work in overtime. Work in overtime is admissible in the cases of: (1) the need to conduct rescue activities in emergencies to protect human life or health, to protect property or the environment or to remove a breakdown of equipment; (2) the employer's special needs.

${ }^{16}$ In accordance with art. $151 \$ 3$ of the labour code, the number of overtime hours worked in connection with the circumstances set forth in $\$ 1.2$ cannot exceed for an individual employee 150 hours in a calendar year. 
The doctrine expresses the view that although the employer's special needs do not formally constitute a limitation in one's providing work in the hours exceeding the contractual norm, still it must be stated that the employer's special needs take place also when, in order to realize the normal employer's objectives, it is necessary to employ employees in additional time as long as the work does not pertain to one specific person in a relatively constant manner. ${ }^{17}$

The National Labour Inspectorate points out that one's refusal to work in excess of contractual hours can be justified in the same situation as one's refusal to work in statutory overtime, i.e. when the request is contrary to law, to the principles of community coexistence, or to one's employment contract. In particular, an employee may prove no special needs on the part of the employer or his own important interest (e.g. performing other earning activities after normal working time or the need to pick his child from preschool or school), the protection of which can take priority over the interest of the employer. The employee can also justify their refusal to perform such a request due to the employer's abusing the law (art. 8 of the labour code) or by discrimination - harassment of the employee (art. $11^{2}$, art. $11^{3}$ and art. $18^{3 \mathrm{a}}-18^{3 \mathrm{e}}$ of the labour code).$^{18}$

Certainly, working extra hours should not be requested with the purpose of performing normal, scheduled tasks nor should it be a permanent element of the organization of work at the employer's as a result of faulty organization of work to compensate for the losses of non-working time arising out of long sickness leaves of other employees, deficiencies in employment, etc. Employment in extra time should be incidental. In every case of repetitive employer's needs, one should consider full-time employment or employment in a higher working time. Thus, I am of the opinion that, due to the essence of part-time employment, an employee should be entitled, to a higher degree, to a possibility to refuse proving work over their contractual working hours, especially if the parties did not make appropriate contractual provisions in this regard. In the first place, the issue should be a subject of agreements between the parties to the employment relationship. As a rule, the employer may not draw negative consequences against a part-time employee in the case when the employee should refuse performing work in the hours exceeding the contractual norm if no agreement, implied or otherwise, was reached in this respect. Such an agreement can be, in particular, a clause on the compensation for working extra hours in the meaning of art. $151 \S 5$ of the labour code as the essence of part-time employment entails lack of the employee's full availability to the employer.

De lege ferenda, I believe that it would be a justified solution to introduce statutory limits for part-time employees' working above contractual hours or prerequisites for providing such work, e.g. to repair a breakdown, where it is necessary to perform a rescue

${ }^{17}$ K. Rączka, Praca w godzinach nadliczbowych w znowelizowanym kodeksie pracy. Thesis No. 4, Praca i Zabezpieczenie Społeczne 2004, 1, item 13.

18 A. Bydłoń, Zdaniem Państwowej Inspekcji Pracy. Thesis No. 1, Praca i Zabezpieczenie Społeczne 2008,12 , item 39 . 
operation in order to protect human life or health. Such solutions exist in French, Italian, and Spanish laws. ${ }^{19}$

\section{Maximum limit of overtime working hours}

In accordance with art. $151 \$ 5$ of the labour code, in their employment contract, the parties should set out the number of extra working hours above the contractual working time, which, if exceeded, shall entitle the employee to a remuneration like for statutory overtime. In the case of exceeding the agreed in the employment contract limit but not exceeding the number of working hours set for full-time working hours, the phenomenon of overtime does not arise but one of hours paid like for overtime. ${ }^{20}$ The question arises, therefore, what is the maximum number of extra hours for which the parties can agree on a bonus remuneration, in particular whether the hours can be counted only after reaching the level of full-time working time, thus the statutory overtime arising out of the labour code, which would have been paid for anyway together with the relevant bonuses provided for in the labour code.

In my opinion, it should be considered inadmissible to set the limit at the level of the norms provided for in the code ( 8 hours per day and the average of 40 hours per week) because, in such a situation, upon exceeding the limits, it is only one's working in statutory overtime that takes place. A contractual provision to this effect would only confirm the right that is guaranteed in the labour code and would not give the employee anything beyond that and, it seems, this was not the intention of the legislator when creating this provision of law.

Furthermore, due to the risk of circumventing the regulations on full-time employment, I believe that it is inadmissible to set the number of hours that entitle one to a bonus under art. $151 \S 5$ of the labour code only at the level of the number of working hours that mean one's working in statutory overtime. ${ }^{21}$ This means that the parties assume full-time employment with no additional compensation for extra contractual hours above the contractual norm. In such a way, a duty is imposed upon the employee not only to provide work in excess of the number of hours agreed upon in the employment contract but also to do so without any gratification therefor.

A similar view was expressed in the literature on labour law. As follows from the said provision of law (art. $151 \S 5$ of the labour code), the parties to an employment relationship have a duty to set out a number of hours above the contractual working

19 See Z. Hajn, Wynagrodzenie pracowników zatrudnionych w niepełnym czasie pracy za pracę $w$ godzinach wykraczających poza umówiony czas a zasada równego traktowania w zatrudnieniu, in: Wynagrodzenie za prace w warunkach społecznej gospodarki rynkowej i demokracji, W. Sanetra (ed.), Warszawa 2009, p. 114.

20 A. Sobczyk, Nowelizacja prawa pracy $w$ zakresie umownego stosunku pracy. Thesis No. 4, Studia z Zakresu Prawa Pracy i Polityki Społecznej 2003, 1, item 117.

21 E. Szemplińska, Konsultacje i wyjaśnienia. Thesis No. 1, Praca i Zabezpieczenie Społeczne 2005, 4, p. 42. 
time specified in the employment contract ("the parties set out"). The number of hours above the contractual working time specified in the employment contract cannot be set out at eight hours per day, i.e. at the level of the statutory working hours norm, because in such a case the employee has the right to extra pay for working statutory overtime under the act as it is statutory overtime work. If, on the other hand, it were about the right to compensation for extra hours, the provision of art. $151 \S 5$ of the labour code would have been completely redundant; an employee who is employed part-time has a right to contractual extra remuneration bonus for contractual extra work that is not yet statutory overtime work. The regulation does not change the definition of statutory overtime - the work above the number of working hours set out in the employment contract (above the contractual working hours but below the statutory norm) is not statutory overtime work; it concerns both the daily norm and the weekly average). ${ }^{22}$

It should be kept in mind that a part-time employee has no benefits arising otherwise out of full-time employment; he is entitled to a proportionately lower amount of annual leave. De lege ferenda, it should be advisable to link the duty to set out the above contractual norm hours payable with a bonus paid like for statutory overtime hours to their admissibility in this amount or to the obligation to work within the hours by a part-time employee.

A failure to accept the work in contractual extra time as statutory overtime means that the limits set forth in art. $151 \S 3$ of the labour code do not apply to it. Although an employee is entitled to the right of 11 hours of an uninterrupted period of rest in each 24 hours, still it should be kept in mind that this entitlement constitutes only a minimum guarantee that serves to secure the employee's right to rest. No limits in one's employment in contractual extra time must undoubtedly be considered as an improper solution, one that can lead to limiting part-time employees' freedom to organize their time and to the distortion of the essence of part-time employment. It is so as it can be assumed that if an employee chooses part-time employment then it means that he wishes to use their free time in a way other than for work. The possibility of ordering a part-time employee to provide full-time work with no restrictions or compensation therefor can significantly restrict employees' intentions.

\section{Remuneration for hours worked above the norm}

In the law as it currently stands, the greatest controversy stirs a situation where the employment contract does not set out the limit of the number of above one's contractual working hours that are paid for with a bonus like for statutory overtime despite the obligation imposed by the legislator. Significant as though it is, the provision itself fails to

\footnotetext{
${ }^{22}$ Ibidem.
} 
establish any sanctions for one's failure to comply with this duty. ${ }^{23}$ The Labour Inspector can find neglecting the duty as an offence against the rights of the employee punishable by a fine of between 1,000 PLN and 30,000 PLN (art. 281.5 of the labour code).

In the literal wording of the provision, it is difficult to find consequences for neglecting this duty, in particular remuneration consequences, although purpose-related considerations speak for their legitimacy. If an employee is obligated to perform work in the hours above the contractual norm then, the work should be paid for additionally. In the literature, opinions are rightly voiced that in such a case the remuneration bonus 'like for statutory overtime' was to be paid for all hours above the number agreed upon. I am of the opinion that such a solution would be in line with the aim of the provision, i.e. the limitation of work over the contractual working time. Furthermore, the essence of the regulation is such that an employee, in general, should work within the agreed upon working time, and their work above the contractual working time, as an exception to one's contractual provisions, should be paid for together with a bonus corresponding to the one like for statutory overtime.

In this regard, surprising is the uniform judicature in the matter that clearly indicates the reverse interpretation. As early as in its judgment of 09 August 1985, I PRN 64/85, the Supreme Court found that an employee who is employed part-time is entitled to a normal remuneration without bonuses for statutory overtime for the work above the working time norm set out in the employment contract. The employee is entitled to bonuses for working in statutory overtime only when the daily or weekly statutory norm of working time provided by law has been exceeded.

However, as at the date of the said judgment being given, neither the current provision of art. $151 \S 5$ of labour law nor an equivalent thereof was in force. So, it would seem that the purpose of introducing the regulation was de facto to eliminate the situation where the part-time employee's hours of work performed above the contractual norm were remunerated according to the rules that apply to full-time work. And yet, upon the introduction of the provisions of art. $151 \$ 5$ of the labour code in the judgment of 09 July 2008, I PK 315/07, ${ }^{24}$ the Supreme Court found that an employee employed parttime is not entitled to the remuneration benefit referred to in art. $151^{1} \$ 1$ of the labour code when the number of admissible number of working hours above the contractual working time pursuant to $151 \S 5$ of the labour code was not set out in the employment contract. In the justification to its judgment, the Supreme Court explained that from the literal interpretation of art. $151 \S 5$ of the labour code followed that this regulation did not qualify the work defined therein as statutory overtime but only established the terms of remuneration and the amount of extra pay for working above the working

${ }^{23}$ It is worth noting that this provisions has been in effect since 2004. The duty to introduce such a provision into the employment contract pertains however also to the agreements concluded prior to amending of the code in this respect, i.e. before 01 January 2004 - the provision had to be incorporated into the agreement by 31 March 2004 (art. 17 of the amending act dated 14 November 2003, Journal of Laws 2003, 2003, item 2081).

${ }^{24}$ OSNP 2009, No. 23-24, item 310. 
time set out in the employment contract (similarly as in art. $138 \$ 1$ of the labour code in reference to working in continuous shifts).

The conclusion that work referred to in art. $151 \S 5$ of the labour code is not work in statutory overtime finds its confirmation in the definition of work in overtime included in art. $151 \S 1$ of the labour code, which pertains to working full-time. This finds its justification in the essence of the regulation on working in statutory overtime hours, which ratio legis constitutes the protection of an employee against additional efforts connected with the work above the maximum norms admissible by law. ${ }^{25}$ Article $151 \S 5$ of the labour code does not constitute an employee's autonomous legal right to compensation for working statutory overtime because such compensation is due if the parties reach an agreement on the admissible number of work hours above the one set out in the employment contract and the legislator imposed the duty to make a relevant contractual provision to this effect, which is obvious due to its consensual character, on both of the parties. The Supreme Court repeated the position expressed in the abovementioned ruling in the decision of 27 March 2012, III PK 77/11. ${ }^{26}$

A similar position in this matter was expressed in the latest Supreme Court judgment of 04 April 2014, I PK 249/13, ${ }^{27}$ in which the Court additionally referred to the judicature of the European Union. In its judgment, the Court pointed out that the legislator defined precisely that only work that is provided above the contractual norm that an employee is obligated to provide as well as the activities performed above the extended daily amount arising out of the current system and schedule of one's working time constitute work in statutory overtime hours. Moreover, it is admissible in the case of the employer's special needs. The Supreme Court pointed out that the issue of the terms on which a part-time employee is entrusted with work above the norm agreed in the employment contract constituted and constitutes the subject of interest and controversy in other European countries as well and that the issue was decided upon in those countries in the same manner as in Poland in the judgment referred to above - I PRN 64/85. ${ }^{28}$

Furthermore, the Supreme Court pointed out that it would be difficult to speak especially about discrimination as regards remuneration for work as it is undeniable that, regardless of the manner in which work in statutory overtime hours is understood (calculated) in art. $151 \S 1$ of the labour code, the rate of part-time employee's pay for extra hours at work above his contractual norm will be kept the same until it reaches the statutory overtime threshold (without bonus remuneration), just like in the case of a full-time employee would work his normal hours. Further, it cannot be held that less favourable treatment consists in forcing an employee to work in excess of the contractual (part-time) limit of hours because the same applies to a full-time employee whom the

${ }^{25}$ See e.g. Supreme Court Judgment of 20 September 1973, II PR 246/73, Nowe Prawo 1974, 9, p. 1200.

${ }^{26}$ LEX, No. 1214595.

${ }^{27}$ LEX, No. 1441344.

${ }^{28}$ Cf. CJEU Judgments in the matter of Helmig et al., C-399/92, in the case No. C-285/02 Elsner v. Lokeberg, in the case No. C-300/06 Ursuia Voss, in: Z. Hajn, Wynagrodzenie pracowników..., p. 114, footnote 4 . 
employer has a right to order to work in statutory overtime, thus in the hours exceeding the set out (full) working time.

It is worth noting that in both cases the mechanism of obligating an employee to work for an additional time is the same, i.e. the duty to perform work arises out of the employee's duty to respect the interest of the work establishment (art. $100 \$ 2.4$ in conjunction with art. $100 \$ 1$ in fine of the labour code). According to the Supreme Court, unjustified is the thesis on violating the principle of proportionality of the remuneration referred to in art. $29^{2} \$ 1$ of the labour code since for the same working time a full-time employee and a part-time employee receive remuneration proportionately to the amount of work whereas extra pay is due for work above the statutory admissible working time unless the parties, in accordance with the provision of art. $151 \$ 5$ of the labour code, set out in the employment contract an payment of a remuneration bonus for extra working hours before reaching the threshold of statutory overtime.

Further, it cannot be held that, due to lack of additional pay for the hours above the ones set out in one's employment contract as contractual working time, a part-time employee is not treated on a par with a full-time employee because he receives the same remuneration for the same work. And the extra pay for statutory overtime is due only for the work above the admissible (the health) norms. The criterion for receiving extra pay is a daily working time of actually performed work and the comparison thereof to the statutory norm, not the contractual daily working time.

Important is the fact that the Supreme Court pointed out that, if one's exceeding a part-time number of working hours should constitute work in statutory overtime, the employee would have been entitled to the remuneration provided for in art. $151^{1}$ of the labour code somewhat automatically. In this context, the mechanism described in $\$ 5$ would mean that a provision in one's employment contract could preclude an employee entitlement arising out of the Act: a contractual provision could have been less favourable than the provision in the Act. It would have resulted in negating the principle of privilege of employees under art. 18 of the labour code.

These rulings were rightfully criticized in the literature $e^{29}$ because rationality considerations speak for it that the omission of this duty should result in the duty to pay remuneration for all hours above the contractual working time norm "like for statutory overtime" (although one should agree with the thesis that it is not statutory overtime). The bonus remuneration is due for work performed above the contractual working time norm set out in the employment contract. With such an interpretation by the Supreme Court, employers have no interest in making relevant agreements with the employees on this issue. An undeniable purpose of introducing the provision was to limit contractual

29 See e.g. O. Likierska, A glos to the Supreme Court Judgement dated 09 July 2008, I PK 315/2007, thesis No. 1, Gdańskie Studia Prawnicze - Przegląd Orzecznictwa 2011, 1, item 165; A. Ornowska, A glos to the Supreme Court Judgment dated 09 July 2008, I PK 315/07, thesis No. 3, Przegląd Sądowy 2010, 11-12, item 194. 
extra hours that exceed the contractual working time norm. An employee gets employed part-time so that, in principle, to work within the agreed working time.

No possibility to award a remuneration bonus can lead to abusing the employee consisting in employers' frequent and deliberate omitting the provisions in employment contracts that arise out of art. $151 \$ 5$ of the labour code. ${ }^{30}$ And it is unlikely that such was the legislator's intention. If upon exceeding the agreed working time, which in the case of a full-time employee is a statutory norm, a full-time employee obtains the right to a higher remuneration, then there are no grounds to accept that the situation will have no legal effects on the part-time employee because he as well should have the right to a higher remuneration ${ }^{31}$ when working extra hours above his contractual working time norm.

In my opinion, the Supreme Court's argumentation that refers to the issues of health and safety at work and health issues warrants criticism as well. In particular, it should be noted that working in statutory overtime is, in principle, admissible within weekly, daily, and annual limits. It means, therefore, that only upon exceeding the statutory norm of 48-hour weekly working time can we speak of issues concerning protection of health and health and safety at work. Until the moment in which it exceeds statutory norms, working statutory overtime is admissible and, at the same time, it is additionally paid for. Therefore, for the same reasons, the work performed by a part-time employee that exceeds the contractual limit set out in the employment contract, without guarantees connected with full-time employment like for instance the right to a longer holiday leave, should be paid additionally as well.

The doctrine also expresses a view that the acceptance that a part-time employee is not entitled to a bonus remuneration without clear agreement on it (by the parties in the employment contract of an admissible number of working hours above the amount of working hours set out in the contract, exceeding which entitles the employee to the bonus remuneration referred to in art. $151^{1} \$ 1$ of the labour code) should be considered strictly as an contra legem act.

For the above reasons, in my view, a more justified position is that, in the case of lack of a relevant provision in the employment contract with the employee, it is the employers on whom the duty should rest to pay remuneration for extra working time upon exceeding the limits of contractual working time for an agreed part-time work. However, due to the current judicial rulings and regulations that are not formulated very precisely, the position in practice can be hard to defend.

${ }^{30}$ A. Ornowska, A glos to the Supreme Court Judgment...

${ }^{31}$ O. Likierska, A glos to the Supreme Court Judgment... 


\section{Summary}

The current Polish regulations concerning part-time employees who work above the contractual working time norms call for the legislator's intervention. First of all, negatively assessed should be the fact of passing the effects of no sanctions to the parties to employment agreements, which set out the limits of the contractual norm of working hours, onto the employee as a party who holds a weaker negotiating position. A similar criticism is due to both the legislator's failure to determine a minimum threshold of contractual extra working hours to be paid for additionally to the contractual working time norm and which are not at the same time statutory overtime, and to formally establishing such a threshold only upon the part-time employee reaching full-time employment by working hours above those constituting his contractual working time norm, which negates the intention behind the regulations. In my opinion, the sanction for the parties' failure to set out the limit of contractual extra hours that are paid for with a remuneration bonus like for statutory overtime should be the employer's duty to pay for all such hours by way of extra remuneration.

My assessment is also negative relating to the lack of any statutory conditions for the admissibility and the limits of a part-time employee's work above his contractual working time limits set out in the employment contract. Such solutions can lead to the employers' easily circumventing the provisions of law concerning full-time employment. It can result in the employers' conducting unrestricted staff and organizational policies, thereby limiting the risk connected with running the employer's business activity at the expense of uncertainty on the part of employees. Such a state of affairs should be considered defective and worthy of the legislator's intervention.

\section{References}

Bydłoń A., Zdaniem Państwowej Inspekcji Pracy. Thesis No. 1, Praca i Zabezpieczenie Społeczne 2008, 12.

Hajn Z., Wynagrodzenie pracowników zatrudnionych $w$ niepełnym czasie pracy za prace w godzinach wykraczajacych poza umówiony czas a zasada równego traktowania w zatrudnieniu, in: Wynagrodzenie za prace $w$ warunkach społecznej gospodarki rynkowej i demokracji, W. Sanetra (ed.), Warszawa 2009.

Kolosa A., Zdaniem Państwowej Inspekcji Pracy, Praca i Zabezpieczenie Społeczne 2005, 11.

Kowalczyk M., Dopuszczalna liczba godzin pracy ponad określony w umowie wymiar czasu pracy, Monitor Prawa Pracy 2010, 4.

Lenart B., Praca w godzinach nadliczbowych. Thesis No. 1, Służba Pracownicza 2004, 6.

Likierska O., A glos to the Supreme Court Judgement dated 09 July 2008, I PK 315/2007, thesis No. 1, Gdańskie Studia Prawnicze - Przegląd Orzecznictwa 2011, 1.

Limit normalnej pracy na część etatu wskazujemy na cztery sposoby, Rzeczpospolita, 1 June 2007, df 2. 
Ornowska A., A glos to the Supreme Court Judgment dated 09 July 2008, I PK 315/07, thesis No. 3, Przegląd Sądowy 2010, 11-12.

Pisarczyk Ł., Commentary to art. 151 of the labour code, in: Kodeks pracy. Komentarz, L. Florek (ed.), LEX/el. 2011.

Rączka K., Praca $w$ godzinach nadliczbowych $w$ znowelizowanym kodeksie pracy. Thesis No. 4, Praca i Zabezpieczenie Społeczne 2004, 1.

Sobczyk A., Nowelizacja prawa pracy w zakresie umownego stosunku pracy. Thesis No. 4, Studia z Zakresu Prawa Pracy i Polityki Społecznej 2003, 1.

Sobczyk A., Prawo do pracy a zatrudnienie terminowe i niepelnowymiarowe, Praca i Zabezpieczenie Społeczne 2016, 11.

Stefański K., \$ 3.2. Godziny nadliczbowe pracowników niepełnoetatowych, in: Czas pracy, Z. Góral, K. Stefański (eds.), LEX 2013.

Szemplińska E., Konsultacje i wyjaśnienia. Thesis No. 1, Praca i Zabezpieczenie Społeczne 2005, 4.

Tomaszewska M., Commentary to art. 29 of the labour code, thesis 11, in: Kodeks pracy. Komentarz, K.W. Baran (ed.), Warszawa 2016.

Wąż P., Problem pracy ponad niepełny wymiar wynikający z umowy o prace, Monitor Prawa Pracy 2009, 11. 